\title{
Suppressive Effect of Astaxanthin on Lipid Peroxidation Induced in Rats
}

\author{
Ikuo Nishigaki, ${ }^{1}$ A. A. DmitrovskiI, ${ }^{1, *}$ Wataru Miki, ${ }^{2}$ \\ and Kunio YAGI ${ }^{1, * *}$ \\ ${ }^{1}$ Institute of Applied Biochemistry, Yagi Memorial Park, Mitake, \\ Gifu 505-01, Japan \\ ${ }^{2}$ Marine Biotechnology Institute, Shimizu Laboratories, \\ Shimizu 424, Japan
}

(Received October 23, 1993)

\begin{abstract}
Summary Astaxanthin, one of the naturally occurring derivatives of vitamin A, was found to suppress lipid peroxidation in a rat liver microsomal system. This substance was also found to suppress lipid peroxidation in rats induced by either carbon tetrachloride or ${ }^{60} \mathrm{Co}$ irradiation. The suppressive effect of astaxanthin on lipid peroxidation was more potent than that of $\alpha$-tocopherol.
\end{abstract}

Key Words: astaxanthin, lipid peroxidation, carbon tetrachloride, ${ }^{60} \mathrm{Co}$-irradiation, $\alpha$-tocopherol

It is our proposal that lipid peroxides increased in the blood are causative of various degenerative diseases such as atherosclerosis [1-3] and cataract $[4,5]$. Therefore, we have regarded suitable antioxidants as prophylactics for these diseases, and have been examining their effects by in vivo experiments. As a result, we have found some antioxidants to be promising [6-11]. Since astaxanthin is expected to be antioxidant from its molecular structure (see Fig. 1), and was reported to inhibit oxidative injury to mitochondrial membrane $[12,13]$, we decided to investigate its effect by a rat liver microsomal system as well as in vivo experimentation. The present antioxidant seems to be more potent than $\alpha$ tocopherol.

\section{MATERIALS AND METHODS}

Materials. A preparation of astaxanthin was kindly donated from Nippon

${ }^{*}$ Present address: A. N. Bach Institute of Biochemistry, Russian Academy of Sciences, Leninsky Prospect 33, Moscow, 117071, Russia.

**To whom correspondence should be addressed. 


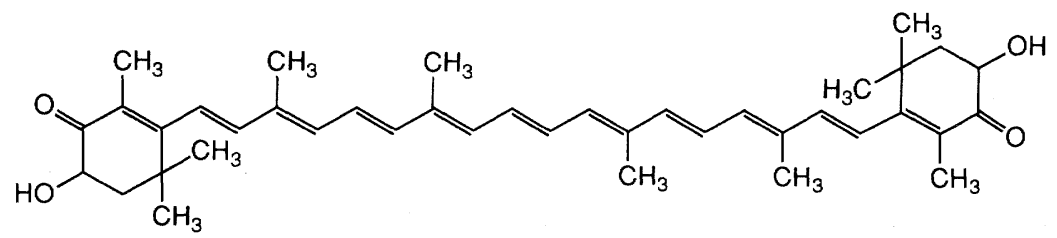

Fig. 1. Structure of astaxanthin.

Roche, Tokyo. Astaxanthin was extracted from the preparation with chloroformethanol mixture $(1: 1, v / v)$. After having been washed with water, the extract was dried over anhydrous sodium sulfate and evaporated. The residue was dissolved in pyridine, and crystallized by addition of water. Astaxanthin recrystallized from an acetone-hexane mixture $(1: 1, \mathrm{v} / \mathrm{v})$ was pure as judged by its UV absorption spectrum. Ellagic acid was purchased from Sigma Chemical Co., St. Louis, MO; DL- $\alpha$-tocopherol (Toc), from Nacalai Tesque, Kyoto; and thiobarbituric acid (TBA), from Tokyo Kasei Kogyo Co., Ltd., Tokyo.

Animals. Male Wistar rats weighing approximately $200 \mathrm{~g}$ were used. The animals were fed a laboratory chow (CE-2, Clea Japan, Inc., Tokyo) ad libitum.

Effect on microsomal lipid peroxidation. Antioxidant effect of astaxanthin on lipid peroxidation in a rat liver microsomal system was studied as described previously [7]. Two milliliters of reaction mixture, which contained $100 \mu \mathrm{M}$ Tris-HCl (pH 7.5), microsomes (ca., $4 \mathrm{mg}$ protein/ml), $4 \mathrm{~mm} \mathrm{ADP,} 12 \mu \mathrm{M} \mathrm{FeCl}_{3}$, $100 \mu \mathrm{M}$ NADPH, and $200 \mu \mathrm{M}$ of either astaxanthin, ellagic acid or Toc dissolved in ethanol, were incubated at $37^{\circ} \mathrm{C}$. Final concentration of ethanol in the reaction mixture was $2 \%$. An aliquot of the reaction mixture was taken for measurement of its lipid peroxide level by the method of Ohkawa et al. [14] and expressed in terms of malondialdehyde. Another aliquot was subjected to protein assay by the method of Lowry et al. [15].

Effect on lipid peroxidation induced in rats by carbon tetrachloride $\left(\mathrm{CCl}_{4}\right)$ administration or ${ }^{60}$ Co-irradiation. To examine the suppressive effect of astaxanthin on lipid peroxidation induced in rats by $\mathrm{CCl}_{4}$, we administered astaxanthin, ellagic acid or Toc through a stomach tube once a day for 3 successive days with fasting for $6 \mathrm{~h}$ before and $3 \mathrm{~h}$ after each administration. The antioxidant was dissolved in ethanol and mixed with olive oil. The final concentration of ethanol was $1 \%(\mathrm{v} / \mathrm{v}) . \mathrm{CCl}_{4}$ was mixed with an equal volume of liquid paraffin, and $0.25 \mathrm{ml}$ of the mixture per $100 \mathrm{~g}$ body weight was given to rats by intraperitoneal injection $3 \mathrm{~h}$ after the final administration of the antioxidant. Control animals were administered olive oil containing $1 \%$ ethanol $(\mathrm{v} / \mathrm{v})$ alone.

To check the effect on lipid peroxidation induced in rats by ${ }^{60} \mathrm{Co}$-irradiation, we gave astaxanthin, ellagic acid or Toc to rats in the same way as in the $\mathrm{CCl}_{4}$ experiments, and $3 \mathrm{~h}$ later a single whole-body ${ }^{60} \mathrm{Co}$-irradiation (10 Gy) was conducted with a Rotational Radio-therapy System (RTGS-2DM; Shimadzu Corp., Kyoto). 
Twenty-four hours after the administration of $\mathrm{CCl}_{4}$ or ${ }^{60} \mathrm{Co}$-irradiation, the rats were anesthetized with ethyl ether, and their blood and organs were taken. The liver was perfused with cold physiological saline. Lipid peroxide levels of the serum and organs were measured by the method of Yagi [16] and that of Ohkawa et al. [14], respectively, and expressed in terms of malondialdehyde.

Other measurements. Activities of glutamate oxaloacetate transaminase (GOT) and glutamate pyruvate transaminase (GPT) in the serum were measured according to the method of Reitman and Frankel [17].

\section{RESULTS AND DISCUSSION}

\section{Effects of astaxanthin on lipid peroxidation in rat liver microsomes}

The antioxidant effect of astaxanthin was first examined in a microsomal lipid peroxidation system. As shown in Fig. 2, astaxanthin remarkably suppressed the lipid peroxidation, and its effect was more potent than that of Toc or ellagic acid. The results are similar to the data of Kurashige et al. [12] on mitochondrial membranes.

Effects of astaxanthin on liver lipid peroxide levels of rats administered $\mathrm{CCl}_{4}$

The lipid peroxide level of the liver of control animals was $1.56 \pm 0.31 \mathrm{nmol} /$ $\mathrm{mg}$ protein (Table 1) or $1.34 \pm 0.15 \mathrm{nmol} / \mathrm{mg}$ protein (Table 2) and that of the serum, $2.02 \pm 0.05 \mathrm{nmol} / \mathrm{ml}$ (Table 2). These values are in good agreement with normal values reported in our previous papers [9-11]. The level in the liver was increased markedly to $5.28 \pm 0.80 \mathrm{nmol} / \mathrm{mg}$ protein by the administration of $\mathrm{CCl}_{4}$.

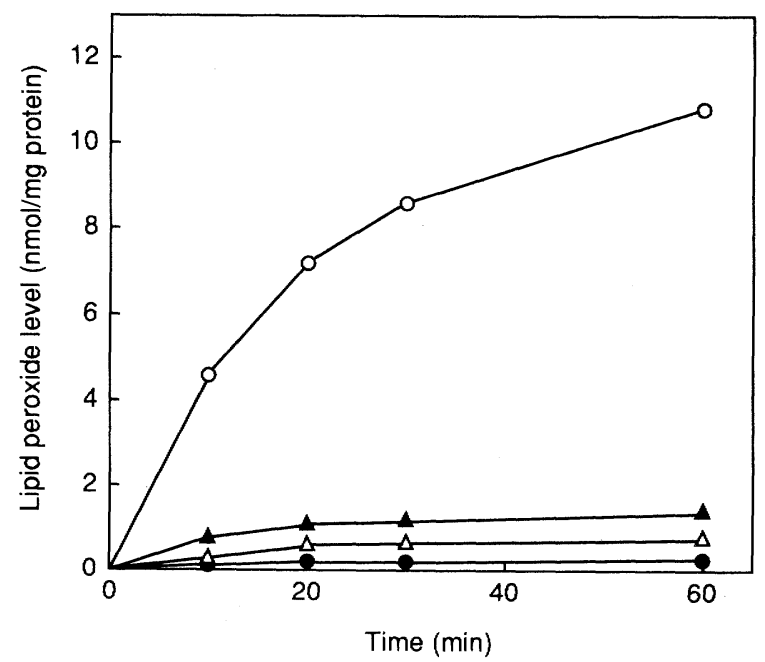

Fig. 2. Effect of astaxanthin on rat liver microsomal lipid peroxidation. For experimental conditions, see text. Open circles, control; closed circles, $200 \mu \mathrm{M}$ astaxanthin; open triangles, $200 \mu \mathrm{M}$ ellagic acid; closed triangles, $200 \mu \mathrm{M}$ Toc. 
Table 1. Effect of astaxanthin, Toc or ellagic acid on liver lipid peroxide levels and serum GOT and GPT of rats administered $\mathrm{CCl}_{4}$.

\begin{tabular}{|c|c|c|c|c|c|c|}
\hline Group & I & II & III & IV & $\mathrm{V}$ & VI \\
\hline $\mathrm{CCl}_{4}$ & - & + & + & + & + & + \\
\hline \multirow{2}{*}{$\begin{array}{l}\text { Additive } \\
\qquad(\mu \mathrm{mol} / \mathrm{kg} \text { body } \\
\text { weight } / \text { day })\end{array}$} & \multirow[t]{2}{*}{-} & \multirow[t]{2}{*}{-} & \multicolumn{2}{|c|}{ Astaxanthin } & Ellagic acid & Toc \\
\hline & & & 5 & 20 & 20 & 200 \\
\hline \multirow{2}{*}{$\begin{array}{l}\text { Lipid peroxide } \\
\text { level of liver } \\
\text { (nmol/mg protein) }\end{array}$} & 1.56 & 5.28 & 3.44 & 2.40 & 3.66 & 3.88 \\
\hline & \pm 0.31 & \pm 0.80 & $\pm 0.18^{*}$ & $\pm 0.22^{* *}$ & $\pm 0.20^{* *}$ & $\pm 0.22 *$ \\
\hline \multirow[t]{2}{*}{ Serum GOT (I.U.) } & 74 & 1443 & 301 & 247 & 280 & 304 \\
\hline & \pm 10 & \pm 58 & $\pm 39 * *$ & $\pm 33 * *$ & $\pm 41 * *$ & $\pm 37^{* *}$ \\
\hline \multirow[t]{2}{*}{ Serum GPT (I.U.) } & 43 & 577 & 82 & 58 & 68 & 80 \\
\hline & \pm 5 & \pm 49 & $\pm 6^{* *}$ & $\pm 5^{* *}$ & $\pm 7^{* *}$ & $\pm 8 * *$ \\
\hline
\end{tabular}

Table 2. Effect of astaxanthin, Toc or ellagic acid on lipid peroxide levels in serum and in various organs of rats irradiated with ${ }^{60} \mathrm{Co}$.

\begin{tabular}{|c|c|c|c|c|c|c|}
\hline Group & I & II & III & IV & V & VI \\
\hline \multirow{3}{*}{$\begin{array}{l}{ }^{60} \text { Co-Irradiation } \\
\text { Additive } \\
(\mu \mathrm{mol} / \mathrm{kg} \text { body } \\
\text { weight } / \text { day })\end{array}$} & \multirow[t]{3}{*}{ - } & \multirow{3}{*}{+} & + & + & \multirow{3}{*}{$\frac{{ }^{+}}{\text {Ellagic acid }}$} & \multirow{3}{*}{$\begin{array}{c}+ \\
\text { Toc } \\
200\end{array}$} \\
\hline & & & \multicolumn{2}{|c|}{ Astaxanthin } & & \\
\hline & & & 5 & 20 & & \\
\hline \multirow{2}{*}{$\begin{array}{l}\text { Lipid peroxide level } \\
\text { Serum }(\mathrm{nmol} / \mathrm{ml})\end{array}$} & 2.02 & 3.07 & 2.27 & 2.06 & 2.24 & 2.69 \\
\hline & \pm 0.05 & \pm 0.25 & $\pm 0.29 * * *$ & $\pm 0.35^{* * *}$ & $\pm 0.21^{* * *}$ & $\pm 0.17^{*}$ \\
\hline \multirow{2}{*}{$\begin{array}{l}\text { Liver } \\
\text { (nmol/mg protein) }\end{array}$} & 1.34 & 2.71 & 1.71 & 1.39 & 1.55 & 1.33 \\
\hline & \pm 0.15 & \pm 0.18 & $\pm 0.23 * * *$ & $\pm 0.06^{* * *}$ & $\pm 0.01^{* * *}$ & $\pm 0.08^{* * *}$ \\
\hline \multirow{2}{*}{$\begin{array}{l}\text { Kidney } \\
\text { (nmol/mg protein) }\end{array}$} & 1.31 & 1.77 & 1.23 & 1.16 & 1.11 & 1.30 \\
\hline & \pm 0.06 & \pm 0.06 & $\pm 0.03 * * *$ & $\pm 0.11^{* * *}$ & $\pm 0.11^{* * *}$ & $\pm 0.11^{* * *}$ \\
\hline \multirow{2}{*}{$\begin{array}{l}\text { Spleen } \\
\text { (nmol/mg protein) }\end{array}$} & 1.26 & 1.57 & 1.34 & 1.31 & 1.30 & 1.16 \\
\hline & \pm 0.09 & \pm 0.17 & \pm 0.15 & $\pm 0.03^{*}$ & $\pm 0.04^{*}$ & $\pm 0.10^{* * *}$ \\
\hline \multirow{2}{*}{$\begin{array}{l}\text { Brain } \\
\text { (nmol/mg protein) }\end{array}$} & 0.48 & 0.79 & 0.51 & 0.51 & 0.83 & 0.48 \\
\hline & \pm 0.14 & \pm 0.16 & $\pm 0.09^{*}$ & $\pm 0.06^{* *}$ & \pm 0.25 & $\pm 0.05^{* *}$ \\
\hline
\end{tabular}

The serum lipid peroxide level, however, was not changed significantly (data not shown).

Astaxanthin was administered to rats through a stomach tube before $\mathrm{CCl}_{4}$ administration, and its effect to suppress lipid peroxidation was then compared with that of ellagic acid or Toc. The results are shown in Table 1. Astaxanthin decreased significantly the lipid peroxide levels of the liver of rats administered 
$\mathrm{CCl}_{4}$ at a dose of $5 \mu \mathrm{mol} / \mathrm{kg}$ body weight/day and decreased it even further at a dose of $20 \mu \mathrm{mol} / \mathrm{kg}$ body weight/day. Ellagic acid and Toc decreased significantly the levels at their doses of 20 and $200 \mu \mathrm{mol} / \mathrm{kg}$ body weight/day, respectively, and these results were in good agreement with the values reported previously [9-11]. The suppressive effects of astaxanthin, ellagic acid, and Toc on the leakage of GOT and GPT were in parallel with their effects on the liver lipid peroxide level. Thus, the effect of astaxanthin was found to be more potent than that of ellagic acid or Toc.

\section{Effects of astaxanthin on lipid peroxide levels in serum and in several organs of rats irradiated with ${ }^{60} \mathrm{Co}$}

The effect of astaxanthin, ellagic acid or Toc on lipid peroxide levels in rats irradiated with ${ }^{60} \mathrm{Co}$ is shown in Table 2. The levels of control animals were increased significantly by the irradiation. Administration of astaxanthin resulted in significant decreases in the levels at a dose of $5 \mu \mathrm{mol} / \mathrm{kg}$ body weight/day or more, and the effect of $20 \mu \mathrm{mol} / \mathrm{kg}$ body weight/day of astaxanthin was approximately the same as ellagic acid and Toc at their doses of 20 and $200 \mu \mathrm{mol} / \mathrm{kg}$ body weight/day, respectively. Inability of ellagic acid to decrease the level of the brain would be ascribed to its incapability to pass through the blood-brain barrier as discussed in our previous paper [18].

From the results reported in this paper, it can be concluded that astaxanthin is a potent antioxidant, and thus promising for clinical application.

\section{REFERENCES}

1. Yagi, K., Ohkawa, H., Ohishi, N., Yamashita, M., and Nakashima, T. (1981): Lesion of aortic intima caused by intravenous administration of linoleic acid hydroperoxide. J. Appl. Biochem., 3, 58-65.

2. Yagi, K. (1984): Increased serum lipid peroxides initiate atherogenesis. BioEssays, 1, 58-60.

3. Yagi, K. (1986): A biochemical approach to atherogenesis. TIBS, 11, 18-19.

4. Yagi, K., Komura, S., Ihara, N., Abe, H., Konishi, H., and Arichi, S. (1985): Serum lipid peroxide levels in rats with inherited cataracts. J. Appl. Biochem., 7, 202-206.

5. Yagi, K., Komura, S., Yoshino, K., and Abe, H. (1989): Serum lipid peroxides and cataractogenesis in riboflavin deficiency. J. Clin. Biochem. Nutr., 6, 39 48.

6. Yagi, K., and Ohishi, N. (1979): Action of ferulic acid and its derivatives as antioxidants. J. Nutr. Sci. Vitaminol., 25, 127-130.

7. Yagi, K., and Komura, S. (1986): Inhibitory effect of female hormones on lipid peroxidation. Biochem. Int., 13, 1051-1055.

8. Yoshino, K., Komura, S., Watanabe, I., Nakagawa, Y., and Yagi, K. (1987): Effect of estrogens on serum and liver lipid peroxide levels in mice. J. Clin. Biochem. Nutr., 3, $233-240$.

9. Ashoori, F., Nishigaki, I., Oku, H., and Abe, H., and Yagi, K. (1990): Suppression by ellagic acid of carbon tetrachloride- or ${ }^{60} \mathrm{Co}$-irradiation-induced lipid peroxidation in rats. J. Clin. Biochem. Nutr., 8, 209-216.

10. Nishigaki, I., Kuttan, R., Oku, H., Ashoori, F., Abe, H., and Yagi, K. (1992): Suppressive effect of curcumin on lipid peroxidation induced in rats by carbon tetrachloride or ${ }^{60}$ Co-irradiation. J. Clin. Biochem. Nutr., 13, 23-29. 
11. Zhou, J., Ashoori, F., Suzuki, S., Nishigaki, I., and Yagi, K. (1993): Protective effect of chlorogenic acid on lipid peroxidation induced in the liver of rats by carbon tetrachloride or ${ }^{60}$ Co-irradiation. J. Clin. Biochem. Nutr., 15, 119-125.

12. Kurashige, M., Okimasu, E., Inoue, M., and Utsumi, K. (1990): Inhibition of oxidative injury of biological membranes by astaxanthin. Physiol. Chem. Phys. \& Med. NMR., 22, $27-38$.

13. Miki, W. (1991): Biological functions and activities of animal carotenoids. Pure Appl. Chem., 63, 141-146.

14. Ohkawa, H., Ohishi, N., and Yagi, K. (1979): Assay for lipid peroxides in animal tissues by thiobarbituric acid reaction. Anal. Biochem., 95, 351-358.

15. Lowry, O.H., Rosebrough, N.J., Farr, A.L., and Randall, R.J. (1951): Protein measurement with the folin phenol reagent. J. Biol. Chem., 193, 265-275.

16. Yagi, K. (1976): A simple fluorometric assay for lipoperoxide in blood plasma. Biochem. Med., 15, 212-216.

17. Reitman, S., and Frankel, S. (1957): A colorimetric method for the determination of serum glutamic oxalacetic and glutamic pyruvic transaminases. Am. J. Clin. Pathol, 28, 56-63.

18. Nishigaki, I., Oku, H., Noguchi, M., Ito, G., Nakanishi, M., and Yagi, K. (1993): Prevention by ellagic acid of lipid peroxidation in placenta and fetus of rats irradiated with ${ }^{60} \mathrm{Co} . J$. Clin. Biochem. Nutr., 15, 135-141. 